\title{
KEDUDUKAN HARTA BERSAMA YANG DIJADIKAN OBJEK JAMINAN HAK TANGGUNGAN DALAM HUTANGPIUTANG DAN DIEKSEKUSI OLEH PENGADILAN (STUDI PUTUSAN NOMOR 13/PDT.BTH/2021/PN TJK)
}

\section{POSITION OF JOINT ASSETS THAT ARE THE OBJECTS OF GUARANTEE OF LIABILITY RIGHTS IN PAYABLES AND EXECUTED BY THE COURT (STUDY OF DECISION NUMBER 13/PDT.BTH/2021/PN TJK)}

\author{
Vindira Shafa Clarisha ${ }^{1}$, Recca Ayu Hapsari ${ }^{2}$, Yulia Hesti ${ }^{3}$ \\ Universitas Bandar Lampung \\ J1. ZA Pagar Alam No 26, Labuhan Ratu, Kecamatan Labuhan Ratu, Kota \\ Bandar Lampung \\ Email : vindria.18211242@student.ubl.ac.id
}

$\begin{array}{ll}\text { Submission } & : \text { 17 Januari } 2022 \\ \text { Accepted } & : \text { 25 Januari } 2022 \\ \text { Publish } & : \text { 31 Januari } 2022\end{array}$

\begin{abstract}
Mortgage rights are regulated in Law Number four of 1996 concerning Mortgage Rights on Land and Objects Related to Land, hereinafter abbreviated as UUHT. With a variety of options 13/pdt.bth/2021/pn/tjk where the land due to the marriage is used as collateral for the rights of borrowing and borrowing through the husband and spouse as guarantors. election No.13/pdt.bth/2021/pn/tjk. The approach used in this study is empirical through interviews with judges at the Tanjung Karang District Court. Land rights that can be encumbered with Borrowing Rights consist of: Ownership Rights, Cultivation Rights, Building Use Rights, and Land Use Rights on state land which in accordance with the legal guidelines and guidelines of the winner must be registered and according to their nature can be transferred. Flats that stand on Ownership Rights, Building Use Rights and Use Rights granted through the state. Because one of the parties, namely Edwin Bunyamin Pohar,was not drawn as a party in the a quo rebuttal case,the rebuttal of the rebuttal as a rebuttal is lacking because not all parties in the main case are parties in the a quo rebuttal case, so the rebuttal of the rebuttal must be declared no acceptable (Niet Onvankelijke Verklaard).
\end{abstract}

Keywords: joint property, mortgage, execution.

Abstark

Hak Tanggungan diatur dalam Undang-Undang Nomor Empat Tahun 1996 tentang Hak Tanggungan atas Tanah dan Benda Yang Berhubungan Dengan Tanah, yang selanjutnya disingkat UUHT. Dengan kisaran pilihan 
13/pdt.bth/2021/pn/tjk, maka barang-barang milik perkawinan tersebut dijadikan jaminan atas hak-hak pinjam meminjam dengan dibantu oleh suami dan isteri sebagai penjamin. Observasi ini bertujuan untuk menambah pengetahuan dan evaluasi terutama berdasarkan seleksi No. 13/pdt.bth/2021/pn/tjk. Teknik yang digunakan dalam penelitian ini adalah berdasarkan fakta, dengan bantuan wawancara dengan hakim Pengadilan Negeri Tanjung Karang. Hak atas tanah yang dapat dibebani hak pinjam terdiri dari hak milik, hak guna usaha, hak guna bangunan, dan hak pakai atas tanah negara yang pada pokoknya berdasarkan pedoman dan peraturan perundang-undangan yang relevan dan dapat dialihkan menurut sifatnya. Rumah Susun yang berdiri di atas hak milik, hak guna bangunan, dan hak pakai yang diberikan dengan bantuan pakai negara. Karena salah satu peristiwa, khususnya Edwin Bunyamin Pohar, tidak lagi dianggap sebagai perayaan kasus sanggahan a quo, sanggahan pihak yang bersengketa sebagai sanggahan hilang karena tidak lagi semua peristiwa dalam pokok perkara merupakan peristiwa untuk kasus sanggahan quo. Akibatnya, sanggahan harus diumumkan. Ini tidak dapat diterima (Niet Onvankelijke Verklaard).

Kata Kunci: harta bersama, hak tanggungan, eksekusi.

\section{A. Pendahuluan}

Dalam sistem hukum jaminan di Indonesia, hipotek adalah jaminan yang dikenakan atas hak atas tanah. Mengenai hak tanggungan, jauh diatur dalam undang-undang nomor 4 tahun 1996 tentang Hak Tanggungan atas Tanah dengan menggunakan benda-benda yang berhubungan dengan Tanah, yang selanjutnya disingkat (UUHT).

Salah satu asas pengaturan yang dianut dalam UUHT adalah asas kekhususan. Dengan menganut asas kekhususan, maka pegadaian memiliki ciri khas yang membedakannya dengan lembaga penjaminan lainnya. Asas ini mensyaratkan bahwa hak tanggungan hanya dapat dikenakan atas tanah yang ditentukan secara khusus. Dihubungkan dengan aturan-aturan materiil, maka hanya pemilik yang sah atau pihak yang memiliki kuasa atas tanah yang dapat menyerahkannya menjadi obyek jaminan hipotek. Sebagaimana ditegaskan oleh Subekti, bahwa seseorang yang memiliki hak milik atas suatu benda dapat melakukan apa saja dengan menggunakan benda tersebut (menjual, menggadaikan, memberi, bahkan merusak), sepanjang tidak melanggar hukum atau hak orang lain. Namun dalam prakteknya untuk menandatangani pemilik yang sah dari suatu benda terkadang sulit, sebagai akibatnya bisa terdapat kasus 
untuk memilih siapa yg sebenarnya memiliki kewenangan terhadap benda tersebut.

Dalam Pasal 8 ayat (1) UUHT ditegaskan bahwa pemberi hipotek adalah orang perseorangan atau badan pengatur yang berwenang untuk melakukan tindakan anggaran terhadap objek hipotek yang bersangkutan. Dalam prakteknya, jika objek hipotek diberikan oleh seorang individu tetapi terikat oleh perkawinan, maka objek jaminan dapat menjadi milik orang (suami/istri) itu sendiri atau harta bersama.

Sesuai dengan aturan harta perkawinan yang diatur dalam KUHPerdata, yang selanjutnya disingkat (KUHPerdata), dampak perkawinan terhadap harta kekayaan suami istri berarti adanya hak milik bersama yang bulat. Hal ini tidak sejalan dengan dampak perkawinan terhadap harta kekayaan perkawinan terhadap harta bersama menurut Undang-Undang Nomor 1 Tahun 1974 tentang Perkawinan, yang selanjutnya disingkat UUP. Dari UUP harta kekayaan tertentu, suami istri tidak mencampuri dan menggunakan sendiri menurut hukum. Hanya harta yang diperoleh selama perkawinan yang dapat menjadi satu dan diyakini sebagai harta bersama. UUP tidak mengatur lebih lanjut tanggung jawab suami istri terhadap harta kekayaannya selama perkawinan.

Harta bersama dalam perkawinan adalah harta bersama suami istri yang diperoleh keduanya selama perkawinan, misalnya ketika seseorang memberikan uang, atau sepeda motor, atau barang lain kepada suami dan istri, atau harta yang dibeli oleh suami dan istri dari uang mereka. , atau Tabungan menurut honorarium suami dan gabungan gaji istri, yang kesemuanya dapat dikategorikan sebagai harta bersama. Pengertian ini selaras dengan pengertian harta bersama sebagaimana tercantum dalam Pasal 35 UU No. 1 Tahun 1974 tentang Perkawinan, yaitu "harta yang diperoleh selama perkawinan menjadi milik bersama". Dalam hal terjadi perceraian, harta bersama akan digolongkan sebagai harta bersama yang pembagiannya ditentukan oleh undang-undang.

Harta bawaan adalah harta kekayaan yang dikuasai oleh masing-masing pemiliknya yaitu suami atau istri. Setiap istri berhak sepenuhnya untuk 
melakukan perbuatan sah mengenai hartanya (Pasal 36 ayat (2) Undang-Undang

Nomor 1 Tahun 1974 tentang Perkawinan). Dalam hal ini, baik KUHPerdata maupun Undang-Undang Perkawinan Nomor 1 Tahun 1974 tentang Perkawinan, yang selanjutnya disingkat Undang-Undang Perkawinan, sama-sama berlaku bagi siapa saja.

Hak Tanggungan adalah penguasaan hak atas tanah yang mengandung kewenangan bagi kreditur untuk berbuat sesuatu terhadap tanah yang dijadikan jaminan. Akan tetapi, bukan untuk dikuasai \& digunakan secara fisik, melainkan untuk dijual jika debitur mengingkari janjinya \& mengambil dari hasilnya seluruhnya atau sebagian sebagai pelunasan utang debitur kepadanya.

Putusan pengadilan adalah produk sah berupa putusan yang dikeluarkan oleh hakim dan merupakan pernyataan sebagai pejabat negara yang berwenang, diucapkan di depan pengadilan yang hasil akhirnya adalah mengakhiri sengketa perkara di antara para pihak yang bersengketa. Putusan tersebut juga merupakan suatu pernyataan yang mempunyai kekuatan shahih mengikat yang diatur dengan undang-undang untuk ditaati dan dilaksanakan.

Dapat dilihat bahwa suatu putusan yang dikeluarkan oleh pengadilan didasarkan pada adanya suatu sengketa atau sengketa, dalam arti putusan tersebut merupakan produk pengadilan dalam perkara contentiosa, yaitu produk pengadilan yang sebenarnya dan disebut yurisdiksi contentiosa, karena ada 2 (dua) pihak yang berseberangan dalam perkara (penggugat). \& terdakwa). Yang dimaksud dengan menggunakan penetapan adalah putusan pengadilan atas suatu perkara permohonan (sukarelawan), misalnya penetapan dalam perkara eksepsi, izin nikah, adhal wali, poligami, perwalian, itsbat nikah, dan sebagainya. Penetapan adalah jurisdiksi valuntaria (bukan pengadilan yang sebenarnya). Karena dalam penetapan hanya ada pemohon, masih belum ada lawan yang sah dan dalam penetapan, Hakim tidak menggunakan kata "putusan" tetapi relatif menggunakan kata "menetapkan". 1

${ }^{1}$ R.Soeroso. 2010. Praktek Hukum Acara Perdata: Tata Cara dan Proses Persidangan. Sinar Grafika, Jakarta, hlm. 5-6. 
Apabila langkah hukum yang diambil merupakan dengan mengajukan gugatan perdata kepada pengadilan hingga sesi berikutnya merupakan menyusun serta merumuskan Gugatan. Dalam perihal untuk menyusun gugatan yang dapat dicoba oleh kuasa hukum merupakan untuk merumuskan duduk perkara, dalam perihal ini wajib terdapat dalil- dalil posita konkret tentang alibi dari gugatan tersebut ataupun Fundamentum Petendi yang terdiri atas bagian yang menguraikan tentang peristiwa ataupun kejadian serta bagian yang menguraikan tentang dasar hukumnya. Dalam formulasi Posita serta Petitum ini wajib terdapat hubungan hukum yang jelas supaya gugatan tersebut bisa diterima, bila tidak gugatan tersebut bisa dianggap obscuur libel (gugatan kabur). Setelah adanya gugatan tersebut barulah masuk dalam proses pengecekan masalah, proses sidang serta yang terakhir merupakan Putusan Hakim yang ialah Putusan Pengadilan.

Terhadap putusan yang dikeluarkan oleh Pengadilan dapat diajukan upaya hukum. Upaya hukum terbagi menjadi 2 (dua) yaitu upaya hukum biasa \& upaya hukum luar biasa (khusus). Upaya hukum biasa adalah upaya hukum yang digunakan untuk putusan yang tidak mempunyai kekuatan hukum tetap \& pada dasarnya dapat menangguhkan eksekusi (kecuali putusan yang dapat dieksekusi terlebih dahulu atau uitvoerbaar bij voorad). Terhadap upaya hukum biasa meliputi: perlawanan/verzet, kasasi yang dilakukan oleh Pengadilan Tinggi \& Kasasi yang dilakukan oleh Mahkamah Agung. Selain upaya hukum biasa, terdapat pula upaya hukum luar biasa (khusus) yaitu upaya hukum yang dilakukan terhadap putusan yang telah mempunyai kekuatan hukum tetap \& pada prinsipnya upaya hukum ini tidak menunda eksekusi. Terhadap upaya hukum luar biasa, antara lain: peninjauan kembali yang dilakukan oleh Mahkamah Agung \& perlawanan/derden verzet pihak ketiga terhadap penyitaan eksekutorial. $^{2}$

${ }^{2}$ Lilik Mulyadi. 2010. Perkara Kepailitan dan Penundaan Kewajiban Pembayaran Utang (PKPU) Teori dan Praktik: Dilengkapi Putusan-Putusan pengadilan Niaga. Alumni, Bandung, hlm. 153-154. 
Dalam putusan yang telah mempunyai kekuatan hukum tetap, eksekusi

dapat dilakukan. Eksekusi adalah suatu tindakan yang dilakukan untuk menyelesaikan suatu perkara yang dijatuhkan kepada pihak yang kalah oleh Pengadilan. Hal ini juga telah diatur dalam HIR atau Peraturan Indonesia yang diperbarui, bab 10, bagian lima atau RBG Judul 4, bagian 4, termasuk mulai dari Pasal 195 sampai dengan Pasal 224 HIR atau mulai dari Pasal 206 sampai dengan Pasal 258 RBG. ${ }^{3}$

Pada pelaksanaan eksekusi harus diajukan terlebih dahulu permohonan pelaksanaan eksekusi kepada Pengadilan Negeri dan atas Penetapan yang dikeluarkan oleh Pengadilan Negeri, Ketua Pengadilan Negeri memberikan perintah untuk melaksanakan eksekusi kepada juru sita atau apabila objek sitaan berada di wilayah hukum/Yurisdiksi Pengadilan Negeri lain maka harus dilakukan terlebih dahulu pendelegasian kepada Pengadilan Negeri setempat dimana objek sitaan berada. Setelah melihat dan mencermati uraian tentang Eksekusi tersebut, ada hal yang sangat menarik untuk disimak bahwa Putusan Pengadilan Niaga tekait perkara Kepailitan memiliki kekuatan hukum tetap sehingga oleh Kurator yang diberikan wewenang oleh Pengadilan berdasarkan Putusan tersebut, dapat segera dilakukan eksekusi berupa pelaksanaan pengurusan dan pemberesan. ${ }^{4}$

Guna memberikan gambaran terhadap permasalahan yang dihadapi, maka akan diuraikan sampel perkara yang digunakan yaitu putusan pengadilan negeri kelas 1A dengan putusan nomor 13/Pdt.Bth/2021/Pn/Tjk dimana objek tanah hasil dari perkawinan dijadikan jaminan hak tanggungan oleh suami dengan istri sebagai penjamin. Dalam perkara sebelumnya yaitu pada putusan nomor 143/Pdt.G/2017/PN.Tjk hal tersebut sudah inkrah dan akan di eksesusi oleh eksekutor, namun ketika akan dieksekusi istri mengajukan bantahan ke

\footnotetext{
${ }^{3}$ M. Yahya Harahap. 2008. Hukum Acara Perdata Gugatan, Persidangan, Penyitaan, Pembuktian dan Putusan Pengadilan. Sinar Grafika, Jakarta, hlm. 300

${ }^{4}$ Recca Ayu Hapsari. 2015. Analisis Hukum Investasi di Pelabuhan Berdasarkan UndangUndang No 17 Tahun 2008 Tentang Pelayaran sebagai Upaya Pembangunan Ekonomi Nasional, Jurnal Peneltiian Hukum, diakses dari https://scholar.google.co.id/citations
} 
pengadilan yang pada pokoknya menyatakan bahwa istri tidak mengetahui persis

persoalan hutang piutang suaminya dan tidak terima tanah tersebut di eksekusi.

Berdasarkan uraian diatas, maka penulis mengangkat permasalahan sebagai berikut:

a. Bagaimanakah kedudukan harta bersama apabila dijadikan sebagai objek jaminan hak tanggungan?

b. Bagaimanakah akibat hukum putusan pengadilan perdata Nomor 13/Pdt.Bth/2021/PN Tjk?

Metode penelitian yang digunakan dalam penelitian ini adalah pendekatan yuridis normatif dan pendekatan empiris. Pengumpulan data dilakukan berdasarkan studi kepustakaan dan studi lapangan, sedangkan pengolahan data dilakukan dengan metode editing, klasifikasi dan sistematisasi data. Narasumber dalam penelitian ini adalah Hakim Pengadilan Negeri Tanjung Karang.

\section{B. Hasil Penelitian dan Pembahasan}

\section{Kedudukan Harta Bersama Apabila Dijadikan Sebagai Objek Jaminan Hak Tanggungan}

Harta Bersama dalam perkawinan adalah harta bersama suami istri yang diterima dengan menggunakan keduanya pada suatu tahap dalam pernikahan mereka, seperti apabila orang memberikan uang, atau sepeda motor, atau barangbarang yang berbeda untuk suami dan istri, atau barang-barang yang dibeli oleh suami dan istri. mitra uang mereka. kolektif, atau tabungan keuangan dari pendapatan suami dan pendapatan istri digabungkan, yang semuanya dapat diberi label sebagai milik bersama.

Pengetahuan ini sesuai dengan pengertian harta bersama sebagaimana tercantum dalam Pasal 35 UU no. 1 Tahun 1974 tentang Perkawinan, khususnya: Ayat (1) mengatur: "Kekayaan yang diperoleh selama perkawinan menjadi milik bersama", kemudian pada ayat(2) disebutkan, "Harta bawaan masing-masing suami istri dan harta benda yang diperoleh masing-masing sebagai hadiah atau 
warisan, berada di bawah penguasaan masing-masing selama peristiwa itu tidak menentukan dalam hal lain".

Pengaturan Pasal 35 UU Perkawinan di atas memiliki kesamaan dengan ketentuan Pasal 36 Undang-Undang Nomor 39 Tahun 1999 tentang Hak Asasi Manusia. Mengingat bahwa kebebasan milik pribadi dan milik bersama adalah hak asasi manusia, penting untuk menekankan secara luas hak milik non-publik dan hak milik bersama dalam sebuah pernikahan. Hal ini karena pada hakikatnya perkawinan berkaitan dengan hak milik non-publik suami atau istri, dan juga berkaitan dengan hak milik bersama antara suami dan istri di beberapa titik perkawinan.

Mengenai harta bersama dalam Islam, menurut Ismail Muhammad Syah seperti dikutip Yahya Harahap, ia mengungkapkan bahwa pencarian dengan suami istri harus dimasukkan dalam rubu'ul muamalah. Namun tidak dibahas secara khusus. Lebih lanjut ia mengungkapkan, mungkin hal ini disebabkan karena pada umumnya penulis berdasarkan kitab-kitab tersebut di atas adalah orang Arab, sedangkan tata cara Arab tidak mengenal tata cara penggeledahan bersama suami istri. Namun, ada masalah kemitraan yang dalam bahasa Arab dianggap sharikah atau syirkah. Mungkin kata syarikah dalam bahasa Indonesia saat ini berasal dari bahasa Arab. Kemudian katanya, karena perkara perceraian dengan suami istri merupakan bagian dari kemitraan atau syirkah. Dalam hal syirkah, katanya, harta bersama termasuk dalam pembahasan syirkah mufawadah \& abdan. Dalam perumusan perkara harta bersama yg masih ada pada Bab XIII yg terdiri dari Pasal 85 hingga Pasal 97, panitia perumus KHI malakukan pendekatan dari jalur aturan syirkah $\&$ adat. $^{5}$

Syirkah dari etimologi adalah campuran, sedangkan dari terminologi adalah jaminan hak atas sesuatu yang dilakukan oleh 2 orang atau lebih pada umumnya,

5 2Yahya Harahap, Kedudukan Kewenangan Dan Acara Peradilan Agama UU. No. 7 Tahun 1989, (Jakarta. Sinar Grafika 2009), H. 270-271 
atau dapat juga dikatakan akad yang menunjukkan hak atas sesuatu yang

dilakukan oleh 2 orang atau lebih menurut pandangan umum. ${ }^{6}$

Telah dijelaskan di atas bahwa perkara harta bersama merupakan tandatanda yg ada semenjak lahirnya Undang-Undang Nomor 1 Tahun 1974 tentang Perkawinan. Pada masa sebelumnya di Indonesia tidak perlu adanya penetapan harta bersama, namun setelah ada keputusan tentang pembagian harta bersama yang wajib, maka pada saat itu umat Islam mencari landasan mengenai harta bersama, karena dalam fiqh ada tidak ada pembahasan tentang harta bersama, oleh karena itu banyak ahli shahih yang mengatakan bahwa perkara harta bersama merupakan penutup ijtihad para ulama saat ini.

Berkaitan dengan yang disampaikan Muhammad Abu Zahroh, mashlahah di sini adalah mashlahah mu'tabarah yang mencakup lima jaminan dasar:

a. Keamanan keyakinan agama.

b. Keamanan jiwa.

c. Keamanan pikiran.

d. Keamanan keluarga \& keluarga.

e. Keselamatan harta benda ${ }^{7}$

Setelah mengetahui pengertian harta bersama, timbul pertanyaan selanjutnya, bagaimana cara memisahkan harta bersama dari Islam? Dalam Islam tidak ada aturan khusus tentang cara membagi harta bersama. Islam hanya memberikan rambu-rambu generik dalam menyelesaikan kasus harta bersama. Pembagian harta bersama tergantung kesepakatan suami istri. Perjanjian ini dalam Al-Qur'an disebut sebagai "Ash Shulhu" yang merupakan perjanjian untuk berdamai antara kedua belah pihak (suami dan istri) setelah terjadi perselisihan.

Menurut peraturan adat, yang dimaksud dengan menggunakan harta perkawinan adalah segala harta benda yang dikuasai oleh suami istri sepanjang dapat diikat dengan ikatan perkawinan, baik harta milik laki-laki maupun perempuan yang berasal dari warisan, harta peninggalan, penghasilan pribadi.

\footnotetext{
${ }^{6}$ Muhammad Abu Zahrah, Alih Bahasa Saefullah. Usul Fikh, (Jakarta: Pustaka Firdaus, 2007), Cet 10, h. 255

${ }^{7}$ Ibid, hal 424.
} 
harta bersama, harta bersama suami istri dan barang-barang lainnya. hadiah.

Dalam perannya sebagai modal kekayaan untuk membiayai kehidupan keluarga suami istri, harta benda perkawinan dapat dikategorikan menjadi beberapa jenis, terutama:

1. Harta benda yang diperoleh suami atau istri sebelum perkawinan, khususnya harta warisan;

2. harta benda yang diterima oleh suami atau istri bagi saya sebelum atau sesudah perkawinan, yaitu harta penghasilan;

3. Harta benda yang diterima dengan menggunakan suami dan isteri secara bersama-sama dalam perkawinan adalah harta nafkah.

4. Harta benda yang diterima bersama oleh suami istri selama berlangsungnya akad nikah adalah pemberian yang kami namakan hadiah pernikahan. ${ }^{8}$

Pengertian hak tanggungan terutama berdasarkan Pasal 1 ayat (1) UndangUndang Nomor 4 Tahun 1996 tentang Hak Tanggungan dan benda-benda yang berkaitan dengan Tanah adalah: Pinjaman adalah hak tanggungan yang dikenakan atas hak atas tanah sebagaimana diatur dalam Undang-Undang Nomor 5 Tahun 1960 tentang UUPA, beserta atau tidak yang meliputi benda-benda lain yang dapat menjadi bagian penting dari tanah, untuk pelunasan utang-utang tertentu, yang mengutamakan kreditur positif di atas kreditur lainnya."

Menurut H. Salim HS, dari pengertian hak tanggungan sebagaimana dijelaskan dalam Pasal 1 ayat (1) Undang-Undang Hak Tanggungan (UUHT), dapat disimpulkan bahwa ada unsur-unsur sebagai berikut:

a. Hak jaminan dibebankan dengan hak atas tanah

b. Hak atas tanah termasuk atau tidak termasuk benda-benda lain yang merupakan satu kesatuan dengan tanah. Hak tanggungan pada dasarnya dapat dibebankan pada hak atas tanah saja, tetapi dapat juga berupa hak atas tanah beserta benda-benda yang ada di atasnya.

\footnotetext{
${ }^{8}$ Evi Juniarti. 2017. Hukum Harta Bersama dari Perspektif UU Perkawinan dan KUH
} Perdata. Jurnal Penelitian Hukum De Jure, Jakarta Selatan, halaman 446. 
c. Untuk melunasi hutang tertentu. Tujuan pelunasan utang tertentu adalah agar hipotek dapat melunasi dan menyelesaikan utang yang terutang oleh debitur kepada kreditur.

d. Mengutamakan kreditur tertentu di atas kreditur lainnya. ${ }^{9}$

Sedangkan menurut Boedi Harsono, hipotek adalah penguasaan hak atas tanah yang memuat kewenangan kreditur untuk berbuat sesuatu terhadap tanah yang dijadikan jaminan. Tetapi bukan untuk dikuasai dan digunakan secara fisik, melainkan untuk dijual jika debitur wanprestasi dan mengambil dari hasilnya seluruhnya atau sebagian sebagai pelunasan utang debitur kepadanya. ${ }^{10}$

Menurut Sutarno, hak tanggungan adalah jaminan yang ada karena telah disepakati sebelumnya antara kreditur dan debiitur. jaminan yang ada atau lahir karena perjanjian ini akan memberikan jaminan khusus dalam bentuk jaminan kebendaan. ${ }^{11}$

Pada dasarnya hak tanggungan dapat dialihkan kepada pihak lain. Pengalihan hak tanggungan diatur dalam pasal 16 sampai dengan 17 UndangUndang Nomor 4 Tahun 1996. Pengalihan hak tanggungan dapat dilakukan dengan cara penyerahan, subrogasi, pewarisan, dan alasan-alasan lainnya. ${ }^{12}$ Subjek hak tanggungan diatur dalam pasal 9 UUHT. Dalam pasal tersebut ditentukan bahwa yang dapat menjadi subjek hukum dalam perbankan adalah pemberi hak tanggungan dan pemegang hak tangggungan. ${ }^{13}$

Untuk dapat dibebani hak tanggungan atas tanah, obyek jaminan harus memenuhi empat syarat, yaitu:

a. Dapat dinilai dengan uang, karena hutang yang dijamin berupa uang.

b. Termasuk hak yang tercantum dalam daftar umum, karena harus memenuhi asas publisitas.

\footnotetext{
${ }^{9}$ H. Salim HS, 2004. Perkembangan Hukum Jaminan di Indonesia. PT Raja Grafindo Persada, Jakarta, hlm 105.

${ }^{10}$ Ibid hlm 96.

${ }^{11}$ Ibid hlm 97.

12 Paputungan Nina, 2016, Kajian Hukum Atas Hak Tanggungan Terhadap Hak Atas Tanah Sebagai Syarat Memperoleh Kredit. Lex Privatum Vol 4 No 2 hlm 5.

${ }^{13}$ Hanavia Evie. 2017. Eksekusi Hak Tanggungan Berdasarkan Title Eksekutorial Dalam Sertifikat Hak Tanggungan. Phd Thesis Srbrlas Maret University.
} 
c. Bersifat dapat dipindahtangankan, karena jika debitur ingkar janji, maka benda yang dijadikan jaminan utang itu akan dijual di muka umum. Sehingga tanah wakaf tidak dapat dibebani hak tanggungan.

d. Memerlukan penunjukan oleh hukum.

Berdasarkan Pasal empat Peraturan Hak Tanggungan, hak atas tanah yang dapat dibebani Hak Tanggungan meliputi:

a. Sebagaimana dimaksud dalam Pasal 4 Ayat (1) UUHT

1) Hak kepemilikan

2) Hak Budidaya

3) Hak Guna Bangunan

b. Yang dimaksud dalam Pasal 4 ayat (2) UUHT adalah hak pakai atas tanah negara yang menurut ketentuan yang bersangkutan harus didaftarkan dan menurut sifatnya dapat dialihkan.

c. Yang dimaksud dengan Pasal 27 UUHT:

Rumah Susun yang berdiri di atas Hak Milik, Hak Guna Bangunan dan Hak Pakai yang diberikan melalui negara. Hak milik atas rumah susun yang rumahnya berdiri di atas tanah dengan Hak Milik, Hak Guna Bangunan dan Hak Pakai yang diberikan melalui negara.

\section{Akibat Hukum Putusan Pengadilan Perdata Nomor 13/Pdt.Bth/2021/Pn Tjk}

Putusan hakim merupakan puncak dari suatu perkara yang sedang diperiksa dan diadili oleh hakim. Hakim memberikan putusannya mengenai hal-hal berikut ini, putusan mengenai peristiwa itu, apakah terdakwa telah melakukan perbuatan yang didakwakan kepadanya. Keputusan mengenai hukum, apakah perbuatan yang dilakukan oleh terdakwa merupakan tindak pidana dan apakah terdakwa bersalah dan dapat dipidana. Keputusan mengenai kejahatan, jika terdakwa memang dapat dihukum. Hakim dalam mengambil keputusan harus berdasarkan atau telah ditentukan oleh undang-undang.

Ketentuan hukum yang selalu tertinggal dari kebutuhan dan perkembangan masyarakat menuntut hakim untuk melakukan kajian hukum yang komprehensif 
yang disebut interpretasi hukum. Berdasarkan teori Ahmad Rifai, konsepsi hakim dalam menafsirkan hukum dapat dibedakan menjadi 2 (dua) teori, yaitu teori penemuan hukum heteronom dan teori penemuan hukum otonom. Perbedaan mendasar antara kedua teori tersebut terletak pada sejauh mana hakim terikat dengan ketentuan hukum tertulis. Teori penemuan hukum heteronom menempatkan hakim sebagai corong hukum, sedangkan teori penemuan hukum otonom menempatkan hakim pada kebebasan untuk memahami dan menghubungkan hukum sesuai dengan perkembangan masyarakat.

Dalam mengkonstruksi suatu putusan, baik dalam perkara pidana maupun perdata, hakim menempuh berbagai pendekatan yang terangkum oleh penulis menjadi 6 (enam) Teori Pemidanaan, seperti yang disampaikan oleh Mackenzie, yaitu:

1. Teori Keseimbangan Putusan Hakim mempertimbangkan keseimbangan antara syarat-syarat di dalam Undang-Undang dan kepentingan pihakpihak yang berkaitan dengan perkara tersebut, misalnya korban, masyarakat, ataupun pihak Penggugat/Tergugat.

2. Teori Pendekatan Seni dan Intiusi Putusan Hakim lebih mempertimbangkan instink atau intuisi dibanding pengetahuan Hukum, sekalipun di dalam Hukum Acara Pidana dikenal sitem pembuktian secara negatif.

3. Teori Pendekatan Keilmuan Putusan Hakim yang mendahulukan dasar ilmu pengetahuan dibandingkan dengan instik atau intuisi. Biasanya pertimbangan Hakim dalam putusannya dipenuhi oleh berbagai macam teori dan doktrin yang berkaitan.

4. Teori Pendekatan Pengalaman Putusan Hakim yang didasarkan pada pengalaman dan jam terbang seorang Hakim dalam memutus suatu perkara. Semakin tinggi jam terbangnya, maka semakin tinggi pula tingkat pemahaman Hakim akan variasi hukum.

5. Teori Ratio Decidendi Putusan Hakim yang mempertimbangkan landasan filsafat yang mendasar. Dalam hal ini, Hakim terlebih dahulu akan mempertimbangkan segala aspek yang berkaitan dengan perkara tersebut 
lalu menemukan ketentutan peraturan perundang-undangan yang tepat untuk dijadikan landasan hukum.

6. Teori Kebijaksanaan Putusan Hakim yang pada mulanya berkenaan dengan Perkara Anak. Teori ini mengandung sebuah pokok pemikiran bahwa di dalam suatu tindak pidana, Pemerintah, Masyarakat, Keluarga (Orang Tua) juga seharusnya ikut bertanggung jawab dalam membina dan membimbing sang anak, sehingga putusan pemidanaan tidak menjadi relevan untuk dikedepankan. ${ }^{14}$

Suami istri secara bersama-sama berhak atas harta bersama karena kedudukan suami istri yang seimbang dalam rumah tangga dan dalam masyarakat. Sebagaimana ditegaskan dalam Pasal 31 ayat (1) UUUP tentang hak dan kewajiban suami istri. Dalam suatu negara yang berdasarkan hukum, cara penyelesaian konflik atau konflik/perselisihan tidak boleh dengan penilaian sendiri, tetapi dengan cara yang diatur sesuai dengan peraturan perundangundangan yang berlaku. Salah satu cara yang dapat ditempuh untuk menyelesaikan konflik atau konflik atau sengketa tersebut adalah melalui jalur pengadilan.

Penyelesaian sengketa di pengadilan pada dasarnya dilakukan dengan cara yang sederhana, cepat dan biaya ringan sebagaimana diatur dalam UndangUndang Nomor 48 Tahun 2009 tentang Kekuasaan Kehakiman Pasal dua ayat (4), Pasal 4 ayat (dua), HIR Pasal 121 ayat (4), 182, 183 dan RBG Pasal 145 ayat (4), Pasal 192 dan Pasal 194. Namun tidak dapat disangkal bahwa berperkara di pengadilan, khususnya dalam perkara perdata, membutuhkan banyak tenaga, waktu dan biaya. Selain itu, proses perdata di pengadilan bisa memakan waktu berbulan-bulan atau bahkan bertahun-tahun. Hal ini terjadi ketika semua upaya

\footnotetext{
${ }^{14}$ Ibid, hlm.20
} 
hukum sah terhadap putusan diambil dari tingkat banding, kasasi dan peninjauan kembali. $^{15}$

Suatu perkara/perselisihan diajukan oleh pihak yang merasa dirugikan ke pengadilan untuk memperoleh penyelesaian atau penyelesaian. Pemeriksaan perkara diakhiri dengan putusan, tetapi perkara tidak selesai dengan putusan saja. Keputusan tersebut harus dapat dilaksanakan atau dipaksakan (eksekusi). Suatu keputusan pengadilan tidak ada artinya bagi pihak yang menang jika tidak dilaksanakan. Oleh karena itu, putusan hakim mempunyai kekuasaan eksekutorial, yaitu kekuasaan untuk melaksanakan apa yang ditetapkan dalam putusan dengan paksa oleh alat-alat negara. Adapun yang memberikan kekuasaan eksekutif, putusan hakim adalah kepala putusan yang berbunyi "Demi Keadilan Berdasarkan Ketuhanan Yang Maha Esa”. Hal ini sesuai dengan Undang-Undang Nomor 48 Tahun 2009 dalam Pasal dua ayat (1) bahwa peradilan dilaksanakan "demi keadilan berdasarkan Ketuhanan Yang Maha Esa". ${ }^{16}$

Hanya putusan hakim yang bersifat condemnatoir (putusan yang diperintahkan atau diktum mengandung unsur "pemidanaan") hanya dapat dilaksanakan, sedangkan putusan hakim yang bersifat konstitutif dan deklaratif tidak memerlukan sarana pemaksaan untuk melaksanakan "non-executable". karena kedua putusan tersebut tidak memuat hak atas suatu prestasi, maka terjadinya akibat yang sah tidak tergantung pada bantuan atau kesediaan pihak yang dikalahkan, sehingga tidak diperlukan cara-cara paksaan untuk melaksanakannya. Jika pihak yang kalah bersedia melaksanakan putusan dengan sukarela, maka perkara perdata dianggap selesai tanpa mendapat bantuan dari pengadilan dalam melaksanakan putusan. Akan tetapi sering terjadi pihak yang kalah tidak mau melaksanakan putusan secara sukarela, sehingga diperlukan bantuan pengadilan untuk menegakkan putusan dengan paksa, dengan cara pihak

${ }^{15}$ Sri Redjeki Slamet. 2013. Tuntutan Ganti Rugi dalam Perbuatan Melawan Hukum: Suatu Perbandingan dengan Wanprestasi, Lex Jurnalica Volume 10 Nomor 2, Agustus 2013, Jakarta, hlm. 2. hlm. 183

${ }^{16}$ Sudikno Mertokusumo. 1999. Mengenal Hukum, Suatu Pengantar. Liberty, Yogyakarta, 
yang menang dalam putusan dapat meminta pelaksanaan putusan kepada pihak yang kalah. pengadilan yang memaksakannya dengan paksa (execution force). ${ }^{17}$

Pelaksanaan putusan pengadilan dalam perkara perdata dilakukan oleh panitera dan juru sita yang dipimpin oleh ketua pengadilan sebagaimana tercantum dalam Pasal fifty four ayat (2) Undang-Undang Nomor forty eight Tahun 2009 tentang Kekuasaan Kehakiman. Selain itu, dalam melaksanakan putusan pengadilan juga perlu memperhatikan nilai-nilai kemanusiaan dan keadilan sebagaimana tertuang dalam Pasal fifty four ayat (3) Undang-Undang Nomor forty eight Tahun 2009 tentang Kekuasaan Kehakiman. Sehubungan dengan pelaksanaan keputusan ini, juga diatur dalam HIR Pasal 195-224 dan RBG Pasal 206-240 RBG dan 258 RBG). Pelaksanaan putusan atas perintah dan di bawah Ketua Pengadilan Negeri yang dimaksud dengan ketua pengadilan negeri yang biasa memeriksa, memutus perkara pada tingkat pertama (Pasal 195 ayat (1) HIR dan RBG Pasal 206 ayat (1)). Dengan kata lain, eksekusi tidak dapat dilakukan oleh Pengadilan Tinggi dan Mahkamah Agung.

Eksekusi dapat dilakukan sesuai dengan tata cara pelaksanaan putusan yang telah mempunyai kekuatan sah tetap, tetapi ada pengecualian yang telah diatur oleh undang-undang, yaitu antara lain:

a. Pelaksanaan putusan yang dapat dijalankan terlebih dahulu menurut Pasal 180 (1) HIR atau Pasal 191 ayat (1) RBG yang memberikan hak kepada penggugat untuk mengajukan permintaan agar putusan dapat dijalankan eksekusinya sekalipun putusan tersebut belum memperoleh kekuatan hukum tetap seperti halnya yang berlaku pada Putusan Permohonan Pernyataan Pailit yang dikeluarkan oleh Pengadilan Niaga sebagaimana diatur didalam Undang-Undang Nomor 40 Tahun 2007 tentang Kepailitan dan Penundaan Kewajiban Pembayaran Utang.

b. Pelaksanaan Putusan Provisi terdapat pula dalam Pasal 180 ayat (1) HIR atau Pasal 191 ayat (1) RBG pada kalimat terakhir yakni tuntutan lebih dulu yang bersifat sementara mendahului putusan pokok perkara.

\footnotetext{
${ }^{17}$ M. Yahya Harahap. 2008. Op. Cit, hlm. 300
} 
c. Adanya Akta Perdamaian yang terdapat dalam Pasal 130 HIR atau Pasal

154 RBG dan saat ini teradapat peraturan tambahan yang dipergunakan

oleh Hakim dalam menentukan lembaga mediasi di Pengadilan yaitu berdasarkan Peraturan Mahkamah Agung (PERMA) Nomor 1 Tahun 2008 tentang Prosedur Mediasi di Pengadilan, walaupun Akta Perdamaian ini bukanlah merupakan putusan yang dapat mengakhiri sengketa perkara, tetapi HIR telah mensejajarkan Akta Perdamaian dengan Putusan yang telah berkekuatan hukum tetap. Akta ini dapat dipergunakan apabila salah satu dari para pihak yang membuat akta perdamaian tersebut ingkar janji untuk dilakukan eksekusi.

d. Eksekusi atas hak tanggungan dan jaminan fidusia berdasarkan Undang undang Nomor 4 Tahun 1996 mengenai hak tanggungan dan Undang- undang Nomor 42 Tahun 1999 tentang jaminan fidusia.

e. Grosse Akta. Pengertian grosse adalah salinan pertama dari akta otentik. Salinan pertama ini diberikan oleh notaris kepada kreditur dengan irahirah (kepala akta) berbunyi, "Demi Keadilan Berdasarkan Ketuhanan Yang Maha Esa", sedangkan salinan lainnya diberikan kepada debitur tanpa irah- irah. Asli akta yang disebut "minit" disimpan oleh notaris juga tidak ada irah-irahnya. ${ }^{18}$

Bahwa maksud dan tujuan bantahan Pembantah adalah bantahan terhadap Penetapan Eksekusi Nomor: 24/Pdt.Eks.PTS/2019/PN.Tjk; sebelum Majelis Hakim mempertimbangkan eksepsi Terbantah I dan pokok perkara Pembantah, Majelis Hakim terlebih dahulu akan mempertimbangkan formalitas bantahan Pembantah; bahwa Pembantah pada pokoknya membantah Penetapan Eksekusi Nomor: 24/Pdt.Eks.PTS/2019/PN.Tjk tanggal 6 Oktober 2020;

Penetapan Eksekusi Nomor: 24/Pdt.Eks.PTS/2019/PN.Tjk tanggal 6 Oktober 2020 merupakan tindak lanjut dari permohonan eksekusi atas perkara nomor: 143/Pdt.G/2017/Pn.Tjk. Pada Pengadilan Negeri Kelas 1 A Tanjung

${ }^{18}$ M. Yahya Harahap. 2010. Ruang Lingkup Permasalahan Eksekusi Bidang Perdata. Sinar Grafika, Jakarta, hlm. 14. 
Karang Jo. Perkara nomor: 36/PDT/2018/PT. Tjk Pada Pengadilan Tinggi

Tanjung Karang Jo. Perkara Nomor: 404K/PDT/2019 pada Mahkamah Agung

Republik Indonesia.

Ada beberapa bentuk dalam undang-undang mengenai pengecualian dalam hal memperkenankan eksekusi dapat dijalankan diluar asas-asas eksekusi. Bentukbentuk pengecualian yang diatur dalam undang-undang adalah sebagai berikut :

a. Pelaksanaan putusan yang dapat dijalankan lebih dulu.

b. Pelaksanaan putusan provisi.

c. Akta perdamaian

d. Eksekusi terhadap Grosse Akta.

e. Eksekusi atas Hak Tanggungan (HT) dan Jaminan Fidusia (JF). ${ }^{19}$

Bahwa pihak-pihak dalam perkara pokok yaitu perkara Nomor: 143 / Pdt.G / 2017 / PN-Tjk. Pada Pengadilan Negeri Kelas 1 A Tanjung Karang adalah sebagai berikut: KOPERASI SERBA USAHA (KSU) JASA PRIMA, sebagai Penggugat; Lawan Edwin Bunyamin Pohar, sebagai Tergugat I; Lisnainy Irdan (Istri dari Tergugat II), sebagai Tergugat II; Notaris Thabrani, sebagai Turut Tergugat.

Pihak-pihak dalam perkara bantahan a quo adalah sebagai berikut: Lisnainy Irdan, sebagai Pembantah; lawan Koperasi Serba Usaha (KSU) Jasa Prima, sebagai Terbantah I; Thabrani, S.H, sebagai Terbantah II; Menimbang, bahwa menurut hukum acara keseluruhan pihak-pihak dalam perkara pokok yaitu perkara Nomor: 143 / Pdt.G / 2017 / PN-Tjk harus sebagai pihak dalam perkara bantahan.

Dengan mencermati pihak-pihak dalam perkara pokok yaitu perkara Nomor: 143 / Pdt.G / 2017 / PN-Tjk tidak semua pihak dalam perkara Nomor: 143 / Pdt.G / 2017 / PN-Tjk ditarik sabagai pihak-pihak dalam perkara bantahan $a$ quo karena Edwin Bunyamin Pohar sebagai Tergugat I dalam perkara Nomor:

\footnotetext{
${ }^{19}$ Ibid, hlm. 9.
} 
143 / Pdt.G / 2017 / PN-Tjk tidak ditarik sebagai pihak dalam perkara bantahan $a$ quo;

Karena ada salah satu pihak yaitu Edwin Bunyamin Pohar tidak ditarik sebagai pihak dalam perkara bantahan a quo, maka bantahan Pembantah sebagai bantahan yang kurang pihaknya karena tidak keseluruhan pihak dalam perkara pokok sebagai pihak-pihak dalam perkara bantahan a quo, sehingga bantahan pembantah haruslah dinyatakan tidak dapat diterima (Niet Onvankelijke Verklaard);

Karena bantahan pembantah dinyatakan tidak dapat diterima, maka Pembantah adalah Pembantah yang tidak benar; Karena bantahan pembantah dinyatakan tidak dapat diterima, maka eksepsi Terbantah I dan pokok perkara bantahan Pembantah tidak perlu dipertimbangkan lebih lanjut;

Karena sanggahan Pembantah dinyatakan tidak dapat diterima, sehingga Pembantah berada pada pihak yang kalah dalam keadaan ini, maka Pembantah dihukum untuk membayar biaya perkara pengadilan; dengan memperhatikan pasal-pasal Undang-undang dan ketentuan-ketentuan kejahatan lain yang relevan;

\section{MENGADILI:}

1. Menyatakan Pembantah adalah Pembantah yang tidak benar;

2. Menyatakankan bantahan Pembantah tidak dapat diterima (Niet Onvankelijke Verklaard);

3. Menghukum Pembantah untuk membayar biaya perkara sejumlah Rp. 785.000,- ( tujuh ratus delapan puluh lima ribu rupiah);

Demikian diputuskan dalam sidang permusyawaratan Majelis Hakim Pengadilan Negeri Tanjung Karang, pada hari Rabu, tanggal 21 Juli 2021.

\section{Penutup}

Hak atas tanah yang dapat dibebani dengan Hak Tanggungan terdiri atas: Hak Milik, Hak Guna Usaha, Hak Guna Bangunan, dan Hak Pakai atas tanah negara yang menurut peraturan perundang-undangan harus didaftarkan dan menurut 
sifatnya dapat dipindahtangankan. rumah susun yang berdiri di atas Hak Milik,

Hak Guna Bangunan dan Hak Pakai yang diberikan oleh negara.

Karena ada salah satu pihak yaitu Edwin Bunyamin Pohar tidak ditarik sebagai pihak dalam perkara bantahan a quo, maka bantahan Pembantah sebagai bantahan yang kurang pihaknya karena tidak keseluruhan pihak dalam perkara pokok sebagai pihak-pihak dalam perkara bantahan a quo, sehingga bantahan pembantah haruslah dinyatakan tidak dapat diterima (Niet Onvankelijke Verklaard).

\section{Daftar Pustaka}

Evi Juniarti. 2017. Hukum Harta Bersama dari Perspektif UU Perkawinan dan KUH Perdata. Jurnal Penelitian Hukum De Jure, Jakarta Selatan.

Hanavia Evie. 2017. Eksekusi Hak Tanggungan Berdasarkan Title Eksekutorial Dalam Sertifikat Hak Tanggungan. Phd Thesis Sebelas Maret University.

H. Salim HS, 2004. Perkembangan Hukum Jaminan di Indonesia. PT Raja Grafindo Persada, Jakarta.

Herzien Inlandsch Reglement (HIR).

Kitab Undang-Undang Hukum Perdata

M Yahya Harahap, 2009. Kedudukan Kewenangan Dan Acara Peradilan Agama UU. No. 7 Tahun 1989, Jakarta. Sinar Grafika

M Yahya Harahap. 2010. Ruang Lingkup Permasalahan Eksekusi Bidang Perdata.Sinar Grafika, Jakarta.

M Yahya Harahap. 2008. Hukum Acara Perdata Gugatan, Persidangan, Penyitaan, Pembuktian dan Putusan Pengadilan. Sinar Grafika, Jakarta.

Muhammad Abu Zahrah, 2007. Alih Bahasa Saefullah. Usul Fikh, Jakarta: Pustaka Firdaus.

Paputungan Nina. 2016. Kajian Hukum Atas Hak Tanggungan Terhadap Hak Atas Tanah Sebagai Syarat Memperoleh Kredit. Lex Privatum Vol 4 No 2

Peraturan Mahkamah Agung (PERMA) Nomor 1 Tahun 2008 tentang Prosedur Mediasi di Pengadilan

Putusan Pengadilan Negeri Tanjung Karang Nomor 13/Pdt.Bth/2021/Pn.Tjk

Rechtsreglement voor de Buitengewesten (R.Bg).

Sri Redjeki Slamet. 2013. Tuntutan Ganti Rugi dalam Perbuatan Melawan Hukum: Suatu Perbandingan dengan Wanprestasi, Lex Jurnalica Volume 10 Nomor 2, Agustus 2013, Jakarta. 
Sudikno Mertokusumo. 1999. Mengenal Hukum, Suatu Pengantar. Liberty, Yogyakarta.

Undang-Undang Dasar Negara Republik Indonesia Tahun 1945 Hasil Amandemen keempat.

Undang-Undang Nomor 5 Tahun 1960 tentang Peraturan Dasar Pokok-Pokok Agraria.

Undang-Undang Nomor 1 Tahun 1974 tentang Perkawinan.

Undang-Undang Nomor 4 Tahun 1996 tentang Hak Tanggungan Atas Tanah Beserta Benda-Benda Yang Berkaitan Dengan Tanah (UUHT).

Undang-Undang Nomor 40 Tahun 2007 tentang Kepailitan dan Penundaan Kewajiban Pembayaran Utang.

Undang-Undang Nomor 48 Tahun 2009 tentang Kekuasaan Kehakiman 